\title{
Iron loading of isolated rat hepatocytes inhibits asialoglycoprotein receptor dynamics and induces formation of rat hepatic leptin-1 (RHL-1) oligomers
}

\author{
Douglas D. MCABEE ${ }^{\star 1}$, Yuan Yuan LING† and Charles STICH* \\ *Department of Chemistry and Biochemistry, California State University, Long Beach, 1250 Bellflower Boulevard, Long Beach, CA 90840-3903, U.S.A., and †Department \\ of Biological Sciences, University of Notre Dame, Notre Dame, IN 46556-5645, U.S.A.
}

The major subunit [rat hepatic lectin-1 (RHL-1)] of the asialoglycoprotein (ASGP) receptor mediates endocytosis of the iron-binding protein lactoferrin (Lf) by isolated rat hepatocytes, yet iron loading of cultured adult rat hepatocytes increases the binding and endocytosis of Lf while greatly inhibiting the uptake of desialylated ligand. In the present study, we determined whether the iron-induced Lf-binding site is RHL-1 and examined the nature of the iron-induced block in ASGP receptor endocytic function. Isolated rat hepatocytes increased their non-haem iron content from 70 to 470 p.p.b. following incubation with ferric ammonium citrate $(\leqslant 100 \mu \mathrm{g} / \mathrm{ml})$. These conditions blocked internalization of ${ }^{125} \mathrm{I}$-asialo-orosomucoid (ASOR) by $\approx 90 \%$ but increased ${ }^{125} \mathrm{I}-\mathrm{Lf}$ endocytosis by $40 \%$. ASOR and anti-RHL1 sera blocked the binding and endocytosis of ${ }^{125} \mathrm{I}-\mathrm{Lf}$ on control cells but not on iron-loaded cells, indicating that the ironinduced Lf-binding site on hepatocytes is not RHL-1. Ironloading of hepatocytes in the presence or absence of excess ASOR did not significantly alter the number of active ASGP receptors on the cell surface. In contrast, iron-loading decreased the number of active intracellular receptors by $40 \%$ and blocked the uptake of ${ }^{125}$ I-ASOR prebound to the cells by $\approx 80 \%$. Under these conditions, we found an iron-dependent evolution of 88 and $140 \mathrm{kDa}$ RHL-1-containing, $\beta$-mercaptoethanol-sensitive multimers that constituted up to 34 and $23 \%$, respectively, of total immunodetectable RHL-1. We propose that iron-induced formation of cystinyl-linked RHL-1-containing multimers inhibits ASGP receptor movement between cell surface and interior and disrupts acylation of intracellular receptors.

\section{INTRODUCTION}

The liver is primarily responsible for iron homoeostasis in mammalian systems. Hepatocytes are particularly adept at iron acquisition and can take up iron by a transferrin-independent iron transporter [1] or by vesicular transport of haem (haemopexin), haemoglobin (haptoglobin), ferritin, lactoferrin (Lf) or transferrin [2]. Under conditions of chronic or acute iron overload, the liver is the primary target site for sequestration of bioactive iron, and iron overloading significantly alters hepatocyte physiology and can give rise to hepatocellular damage and liver dysfunction [3-9]. Exposure of various cells to iron can result in modification of cell components and altered cell behaviour. For instance, haemin or non-haem iron inhibits the erythrocyte $\mathrm{Ca}^{2+} / \mathrm{Mg}^{2+}$-ATPase through oxidation of permease thiols [10] or of permease-associated phospholipids [11], and exposure of erthrocytes to $\mathrm{Fe}^{3+}$ promotes their dithiothreitolreversible recognition by resident and activated macrophages [12]. In general, pharmacologic agents that induce cytotoxicity by promoting an oxidative shift in the cellular thiol-disulphide redox status can induce their effects in part by $\mathrm{Fe}^{3+}$-dependent oxidation events $[9,13,14]$.

We have examined the effects of hepatocyte iron status on hepatocyte binding and endocytosis of Lf. We have found that isolated rat hepatocytes bind and internalize $\mathrm{Lf}$ in a $\mathrm{Ca}^{2+}$ dependent manner via the major subunit [rat hepatic leptin-1 (RHL-1)] of the asialoglycoprotein (ASGP) receptor $[15,16]$. Surprisingly, RHL-1 binds Lf with high affinity $\left(K_{\mathrm{d}} \approx 10^{8} \mathrm{nM}\right)$ independent of the presence of terminal galactosyl or $N$-acetylgalactosaminyl sugars on Lf's lactosaminyl-type oligosaccharide chains [16]. Cultured adult rat hepatocytes increase Lf binding and endocytosis up to sixfold following incubation with the ferric salt ferric ammonium citrate (FAC) [17]. Iron-induced appearance of elevated Lf binding sites is blocked by cycloheximide but not by actinomycin D [17], suggesting the possibility that expression of these iron-dependent Lf-binding sites is governed by an iron-response element/iron-regulatory protein-dependent translational control mechanism [18]. It is unlikely that RHL-1 is responsible for the iron-dependent increase in Lf binding and endocytosis observed in FAC-treated cells for two reasons. First, RHL-1 mRNAs do not possess an iron-regulatory element. Secondly, sustained endocytosis of asialo-orosomucoid (ASOR; a high-affinity ligand for the ASGP receptor) is diminished up to $80 \%$ in iron-loaded hepatocytes [17]. In light of these observations, the focus of the present study was twofold: (i) determine whether the iron-induced Lf-binding site was RHL-1, and (ii) explain the nature of the iron-induced block in ASGP receptor endocytic function. We report here that iron-loaded isolated rat hepatocytes express a second, non-RHL-1 Lf-binding site that mediates their endocytosis of Lf. We also provide evidence that iron loading selectively blocks internalization and recycling of the ASGP receptor and induces the accumulation of inactive receptors intracellularly. These effects correlate with the ironinduced appearance of disulphide-bonded RHL-1-containing multimers, suggesting that ASGP receptor dynamics are sensitive to the oligomeric nature of RHL-1.

\section{MATERIALS AND METHODS}

\section{Materials}

Human ASOR, bovine colostrum Lf, BSA (fraction V), dextran sulphate (5000 Da), FAC and neuraminidase (Clostridium perfringens) were purchased from Sigma (St. Louis, MO, U.S.A.).

Abbreviations used: ASGP, asialoglycoprotein; ASOR, asialo-orosomucoid; BME, basal medium Eagle's; FAC, ferric ammonium citrate; HBS, Hepesbuffered saline; Lf, lactoferrin; RHL, rat hepatic lectin.

1 To whom correspondence should be addressed (e-mail dmcabee@csulb.edu). 
FAC contains $16.5-18 \% \mathrm{Fe}$ as assayed by the manufacturer. Collagenase (Type D) was from Boehringer Mannheim (Indianapolis, IN, U.S.A.). 1,3,4,6-Tetrachloro-3 $\alpha, 6 \alpha$-diphenylglycouril (Iodogen) was from Pierce Chemical Co. (Rockford, IL, U.S.A.), and $\mathrm{Na}^{125} \mathrm{I}$ was from DuPont New England Nuclear (Boston, MA, U.S.A.). $\mathrm{FeCl}_{3}$ standard solution was obtained from Fisher Biochemicals (Itasca, IL, U.S.A.). All other chemicals were reagent grade and obtained from Fisher. Hepes-buffered saline (HBS) contained $150 \mathrm{mM} \mathrm{NaCl}, 3 \mathrm{mM} \mathrm{KCl}$ and $10 \mathrm{mM}$ Hepes, $\mathrm{pH}$ 7.4. Buffer A contained HBS supplemented with $5 \mathrm{mM} \mathrm{CaCl}_{2}$ and $5 \mathrm{mM} \mathrm{MgCl}_{2}$. Buffer B contained Buffer A supplemented with $0.3 \%(\mathrm{w} / \mathrm{v})$ dextran sulphate. Buffer $\mathrm{C}$ contained $500 \mathrm{mM} \mathrm{NaCl}, 3 \mathrm{mM} \mathrm{KCl}, 5 \mathrm{mM}$ EGTA, $10 \mathrm{mM}$ Hepes, pH 7.4, and $0.3 \%(\mathrm{w} / \mathrm{v})$ dextran sulphate. Buffer D contained HBS and 5 mM EGTA. Basal medium Eagle's (BME) was obtained from Sigma and supplemented with $2.4 \mathrm{~g} / 1$ Hepes, $\mathrm{pH} 7.4$, and $0.22 \mathrm{~g} / 1 \mathrm{NaHCO}_{3}$. BME/BSA is BME containing $0.1 \%(\mathrm{w} / \mathrm{v})$ BSA.

\section{Hepatocytes}

Male Sprague-Dawley rats (150-350 g; Harlan Labs, Indianapolis, IN, U.S.A.) were fed standard laboratory chow and water ad libitum. The iron content of the chow (Purina Rodent Laboratory Chow, formula 5001) was 198.0 p.p.m. as assayed by the manufacturer. Hepatocytes were prepared by a modification of a collagenase perfusion procedure [19] as described previously [20]. Cells were kept at $\approx 30^{\circ} \mathrm{C}$ during the filtration and differential centrifugation steps. Final cell pellets suspended in ice-cold BME/BSA were $\approx 85 \%$ viable and single cells. Before experiments, cell suspensions $\left[(2-4) \times 10^{6}\right.$ cells $/ \mathrm{ml}$ in BME/BSA; $10 \%$ of the flask volume] were incubated at $37^{\circ} \mathrm{C}$ for $60 \mathrm{~min}$ to allow recovery from the isolation procedure. Viability was determined microscopically by Trypan Blue exclusion.

\section{ASOR and Lf preparation}

Human orosomucoid was desialylated with neuraminidase as described previously [21], and removal of terminal $\mathrm{N}$-acetylneuraminyl groups was confirmed by lectin blotting of neuraminidase-treated orosomucoid with Sambucus nigra agglutinin-digoxigenin conjugate (DIG Glycan Differentiation Kit; Boehringer Mannheim) as reported elsewhere [16]. Bovine colostrum Lf (commercial preparation $>90 \%$ pure electrophoretically) at $5 \mathrm{mg} / \mathrm{ml}$ in $100 \mathrm{mM} \mathrm{KCl} / 10 \mathrm{mM}$ potassium phosphate, $\mathrm{pH} 7.2$, was further purified by ion-exchange chromatography as described previously [20]. Lf's iron content (determined spectroscopically from its $A_{465}: A_{280}$ ratio) was routinely $0.03-0.035$, indicating $\approx 75 \%$ iron saturation $[22,23] .{ }^{125} \mathrm{I}-\mathrm{ASOR}$ and ${ }^{125} \mathrm{I}-$ Lf, prepared by the 'Iodogen' method [24], had specific activities of 10-60 d.p.m./fmol. Homogeneity and structural integrity of radiolabelled and unlabelled ASOR and Lf used for these studies was confirmed by SDS/PAGE and autoradiography.

\section{Binding and endocytosis assays}

For Lf binding assays, $(2-4) \times 10^{6}$ cells $/ \mathrm{ml}$ were routinely incubated with ${ }^{125} \mathrm{I}$-Lf or ${ }^{125} \mathrm{I}$-ASOR at $4{ }^{\circ} \mathrm{C}$ for $90 \mathrm{~min}$ in either $\mathrm{BME} / \mathrm{BSA}$ or Buffer A. Cells incubated with ${ }^{125} \mathrm{I}-\mathrm{Lf}$ were washed free of unbound radiolabelled ligand by centrifugation in excess Buffer B (two 10 min washes, $4^{\circ} \mathrm{C}$ ), whereas cells incubated with ${ }^{125}$ I-ASOR were washed free of unbound ligand by centrifugation in excess Buffer A (two 5 min washes, $4^{\circ} \mathrm{C}$ ). Washed cells were resuspended in $0.5-1.0 \mathrm{ml}$ of Buffer $\mathrm{A}$, transferred to clean plastic tubes and assayed for radioactivity and protein. In some cases, hepatocytes were permeabilized with $0.055 \%(\mathrm{w} / \mathrm{v})$ digi- tonin before addition of ${ }^{125}$ I-ligand in order to measure the surface and intracellular pools of receptor activity on cells [25]. To measure hepatocyte endocytosis of ${ }^{125} \mathrm{I}-\mathrm{Lf}$ and ${ }^{125} \mathrm{I}$-ASOR, cells in BME/BSA were incubated with ${ }^{125} \mathrm{I}$-Lf or ${ }^{125} \mathrm{I}$-ASOR at $37^{\circ} \mathrm{C}$ for $45-60 \mathrm{~min}$. Uptake was stopped rapidly by diluting the cells into a 5-10-fold excess volume of ice-cold Buffer A $\left({ }^{125} \mathrm{I}\right.$ ASOR) or Buffer B ( $\left.{ }^{125} \mathrm{I}-\mathrm{Lf}\right)$. To assay total cell-associated (surface and intracellular) ${ }^{125} \mathrm{I}-\mathrm{Lf}$ and ${ }^{125} \mathrm{I}$-ASOR, cells were washed by centrifugation twice in 2-4 $\mathrm{ml}$ of cold Buffer $\mathrm{B}$ and Buffer A respectively. To assay internalized ${ }^{125} \mathrm{I}-\mathrm{Lf}$ and ${ }^{125} \mathrm{I}-$ ASOR only, cells were washed by centrifugation twice, $10 \mathrm{~min}$ each wash, in 2-4 $\mathrm{ml}$ of Buffer $\mathrm{C}$ and Buffer D, respectively, at $4{ }^{\circ} \mathrm{C}$. After washing, cells were resuspended in $0.5-1.0 \mathrm{ml}$ of Buffer A, transferred to clean plastic tubes and assayed for radioactivity and protein.

\section{Electrophoresis and immunoblotting}

Samples for electrophoresis were denatured in $63 \mathrm{mM}$ Tris $/ \mathrm{HCl}$ $(\mathrm{pH} 6.8) / 2 \%$ (w/v) SDS $/ 10 \%$ (v/v) glycerol $/ 0.01 \%(\mathrm{w} / \mathrm{v})$ Bromophenol Blue, heated for $5 \mathrm{~min}$ at $100^{\circ} \mathrm{C}$, and electrophoresed at $200 \mathrm{~V}$ on a $4-15 \%$ acrylamide $\mathrm{Tris} / \mathrm{HCl}$ slab gel using a Mini-Protean II slab gel apparatus (BioRad). Fractioned polypeptides were electrophoresed to nylon-supported nitrocellulose (BioRad) in $0.15 \mathrm{M}$ glycine $/ 20 \mathrm{mM}$ Tris $/ 20 \%(\mathrm{v} / \mathrm{v})$ methanol at $200 \mathrm{~mA}$ for $45 \mathrm{~min}$. Nitrocellulose was blocked for $1 \mathrm{~h}$ in Tris-buffered saline $(500 \mathrm{mM} \mathrm{NaCl}$ and $20 \mathrm{mM}$ Tris/ $\mathrm{HCl}$, $\mathrm{pH}$ 8.0) supplemented with $0.1 \%$ Nonidet P-40, and $5 \%(\mathrm{w} / \mathrm{v})$ BSA, then probed with rabbit anti-RHL-1 serum [15] (1:200) in blocking buffer for $2 \mathrm{~h}$ at $22{ }^{\circ} \mathrm{C}$. Papers were washed twice, 10 min per wash, with Tris-buffered saline supplemented with $0.1 \%(\mathrm{v} / \mathrm{v})$ Nonidet P-40, $0.25 \%$ (w/v) sodium deoxycholate and $0.1 \%(\mathrm{w} / \mathrm{v})$ SDS, then rinsed with Tris-buffered saline. Immobilized rabbit antibody was detected by incubating the papers in blocking buffer containing goat anti-rabbit alkaline phosphatase conjugate $\mathrm{IgG}$ (BioRad; $1: 3000)$ for $1 \mathrm{~h}$ at $22^{\circ} \mathrm{C}$. Papers were washed as before and developed for alkaline phosphatase activity per manufacturer's instructions. Developed papers were scanned by an Ultroscan XL laser densitometer and analysed using Gelscan XL software (Pharmacia LKB).

\section{Determination of hepatocyte non-haem iron content}

Hepatocytes incubated with and without FAC $\left(10^{6}\right.$ cells/sample $)$ were heated in $1.0 \mathrm{ml}$ of $2.8 \mathrm{M} \mathrm{HNO}_{3}$ for $1 \mathrm{~h} \mathrm{at} 90{ }^{\circ} \mathrm{C}$, then centrifuged $\left(12000 \mathrm{~g}, 10 \mathrm{~min}, 4^{\circ} \mathrm{C}\right)$ to remove insoluble debris. Clarified supernatants were diluted into water to give a final $\mathrm{HNO}_{3}$ concentration of $0.11 \mathrm{M}$ and stored at $22^{\circ} \mathrm{C}$ in glass vials previously washed overnight with $0.5 \%(\mathrm{v} / \mathrm{v}) \mathrm{HNO}_{3}$ and rinsed thoroughly with distilled water. In some instances, manipulations were performed on samples in which cells were omitted to determine the amount of background assayable iron present. Iron content was measured by inductively coupled plasma MS using a VG PlasmaQuad II mass spectrophotometer (Fisons Instruments, Beverly, MA, U.S.A.) with $\mathrm{FeCl}_{3}$ as a standard (Notre Dame Center for Bioengineering and Pollution Control).

\section{General}

Protein was determined by the bicinchoninic acid protein assay procedure using BSA as standard (Pierce). Centrifugation of cell suspensions was at $400 \mathrm{~g}$ for $2 \mathrm{~min}$ at $4{ }^{\circ} \mathrm{C}$ (Sorvall RT6000B centrifuge; DuPont, Wilmington, DE, U.S.A.). ${ }^{125}$ I radioactivity was determined using a Packard Cobra Auto-Gamma counting system (Model 5002; Packard Instrument Co., Downers Grove, IL, U.S.A.). Spectroscopic measurements were done using a 
Beckman DU-64 spectrophotometer (Fullerton, CA, U.S.A.) or a Shimadzu UV-160 spectrophotometer (Kyoto, Japan).

\section{RESULTS}

\section{Iron-dependent inhibition of ASGP receptor activity}

We have shown previously that iron loading of primary cultures of adult rat hepatocytes with FAC $(1 \mu \mathrm{g} / \mathrm{ml}, 16-20 \mathrm{~h})$ blocks endocytosis of the desialylated glycoprotein ASOR [17]. The endocytic block was accompanied by up to a $60 \%$ decrease in the total number of active ASGP receptors with no loss in immunodetectable ASGP receptor protein, suggesting that iron loading induced the endocytic block of ASOR by causing cells to accumulate inactive ASGP receptors intracellularly [26]. If iron loading induced alterations in ASGP receptor processing, we reasoned that such effects might also be observed on isolated rat hepatocytes in suspension treated for relatively shorter times with higher FAC concentrations. To examine this, isolated hepatocytes in suspension were treated with various FAC con-
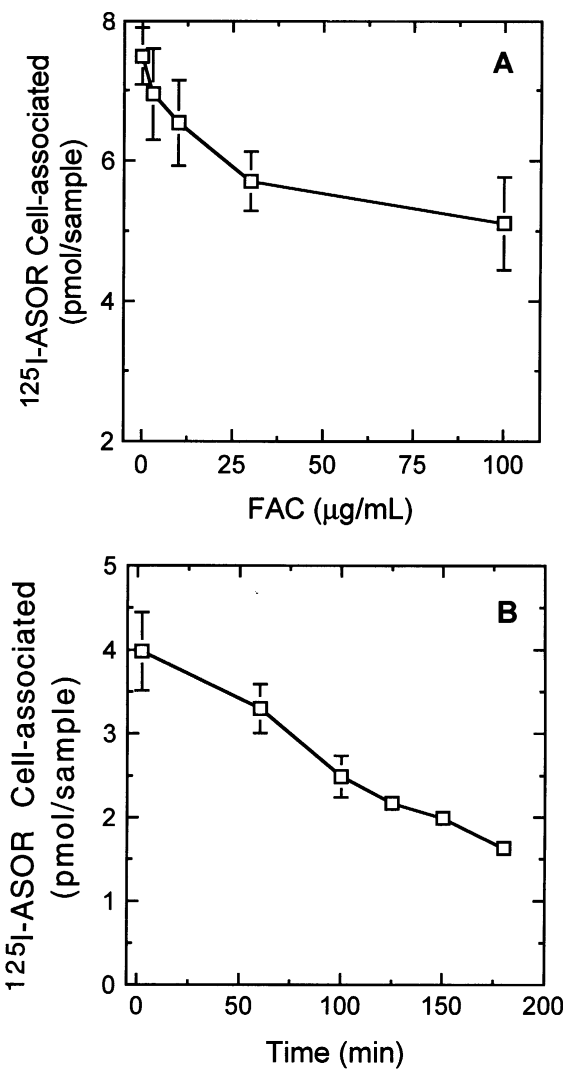

Figure 1 Effects of iron loading of isolated hepatocytes on ASGP receptordependent endocytosis

(A) Hepatocytes $\left(2 \times 10^{6}\right.$ cells $\left./ \mathrm{ml}\right)$ were incubated in BME/BSA with the designated concentrations of FAC at $37^{\circ} \mathrm{C}$ for $1 \mathrm{~h}$. Samples were supplemented with ${ }^{125} \mathrm{I}$-ASOR $(5 \mu \mathrm{g} / \mathrm{ml})$, and the $37^{\circ} \mathrm{C}$ incubation was continued for an additional $1 \mathrm{~h}$, after which the cells were chilled on ice. Cells were washed and assayed for total cell-associated radioactivity as described in the Materials and methods section. Values represent means of quadruplicate samples; error bars reflect S.D. values of means. (B) Hepatocytes $\left(2 \times 10^{6} \mathrm{cell} / \mathrm{sl}\right)$ were incubated in BME/BSA supplemented with $100 \mu \mathrm{g} / \mathrm{ml} \mathrm{FAC}$ at $37^{\circ} \mathrm{C}$. At the designated times, samples were supplemented with ${ }^{125} \mathrm{I}-\mathrm{ASOR}(5 \mu \mathrm{g} / \mathrm{ml})$ and incubated an additional $45 \mathrm{~min}$ at $37^{\circ} \mathrm{C}$, after which cells were chilled, washed and assayed for total cell-associated radioactivity as described in the Materials and methods section. Values represent means of triplicate samples; error bars reflect S.D. values of means.

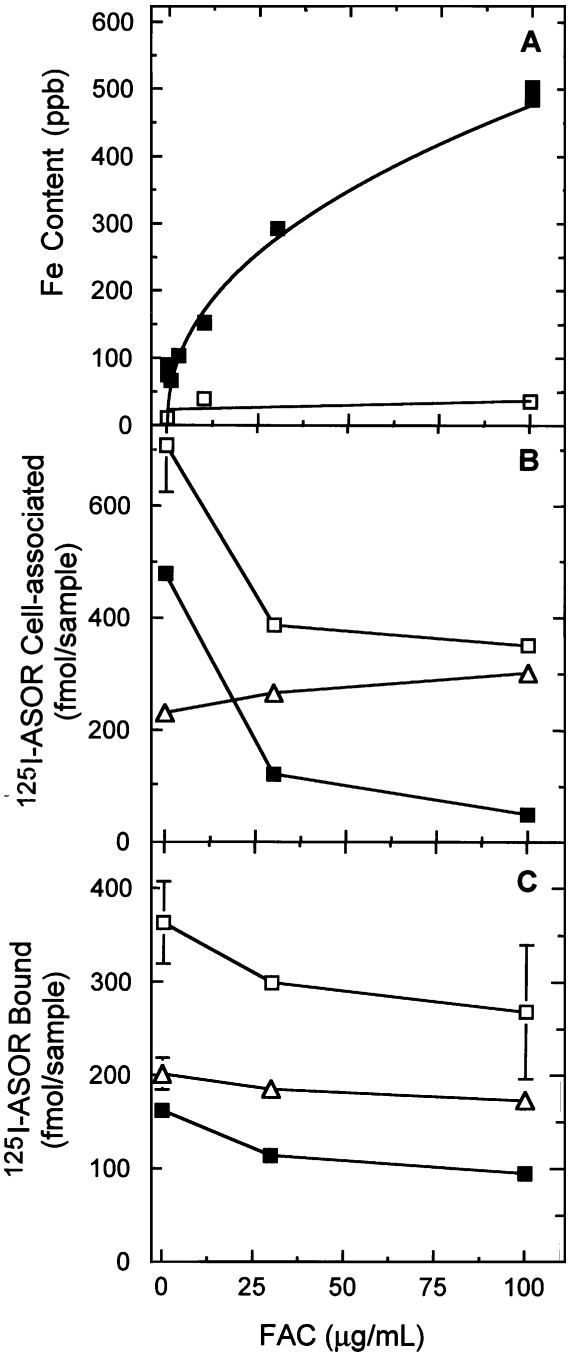

Figure 2 Effects of FAC treatment on hepatocyte iron content, ASOR endocytosis and total cellular ASGP receptor ligand-binding activity

(A) Hepatocytes $\left(3 \times 10^{6}\right.$ cells $\left./ \mathrm{ml}\right)$ were incubated in BME/BSA with the designated concentrations of FAC for $2 \mathrm{~h}$ at $37^{\circ} \mathrm{C}$. The cells were chilled and assayed for non-haem iron content ( $\boldsymbol{\square}$ ) as described in the Materials and methods section. A parallel set of incubations was performed in the absence of cells $(\square)$ to determine the amount of iron absorbed nonspecifically to the incubation wells. $($ B $)$ Hepatocytes $\left(2.4 \times 10^{6}\right.$ cells $\left./ \mathrm{ml}\right)$ were incubated in BME/BSA with the designated concentrations of FAC for $3 \mathrm{~h}$ at $37^{\circ} \mathrm{C}$, then supplemented with ${ }^{125} \mathrm{I}$-ASOR $(2 \mu \mathrm{g} / \mathrm{ml})$ and incubated an additional $1 \mathrm{~h}$ at $37^{\circ} \mathrm{C}$. The cells were chilled and washed in either Buffer $\mathrm{A}(\square)$ to determine total cell-associated radioactivity or in Buffer $\mathrm{D}($ to assay for internalized radioactivity as described in the Materials and methods section. Surface-bound ${ }^{125} \mathrm{I}-\mathrm{ASOR}(\triangle)$ was calculated as the difference between total cell-associated and internalized ${ }^{125}$ I-ASOR. (C) Hepatocytes $\left(2.4 \times 10^{6} \mathrm{cell} / \mathrm{ml}\right)$ were treated with or without FAC as for (B), then chilled on ice and assayed for ${ }^{125} \mathrm{I}$-ASOR binding at $4{ }^{\circ} \mathrm{C}$ in the presence $(\square)$ or absence $(\triangle)$ of $0.055 \%$ digitonin to assay, respectively, for total (surface and intracellular) and surface ASGP receptor ligand-binding activity as described in the Materials and methods section. ${ }^{125} \mathrm{I}$-ASOR binding to intracellular ASGP receptor sites alone ( $\boldsymbol{\square}$ ) was calculated as the difference between ${ }^{125}$ I-ASOR binding to intact or permeable hepatocytes. Values shown in all three panels represent means of duplicate assays; error bars reflect S.D. values of means.

centrations for $1 \mathrm{~h}$ then assayed for ${ }^{125} \mathrm{I}$-ASOR endocytosis in the presence of FAC for an additional hour (Figure 1A). Under these conditions, hepatocyte endocytosis of ${ }^{125}$ I-ASOR was progressively reduced up to $32 \%$ at FAC concentrations up to $100 \mu \mathrm{g} / \mathrm{ml}$. We also found that the FAC-dependent inhibition of ${ }^{125}$ I-ASOR endocytosis was also time dependent, in that binding 

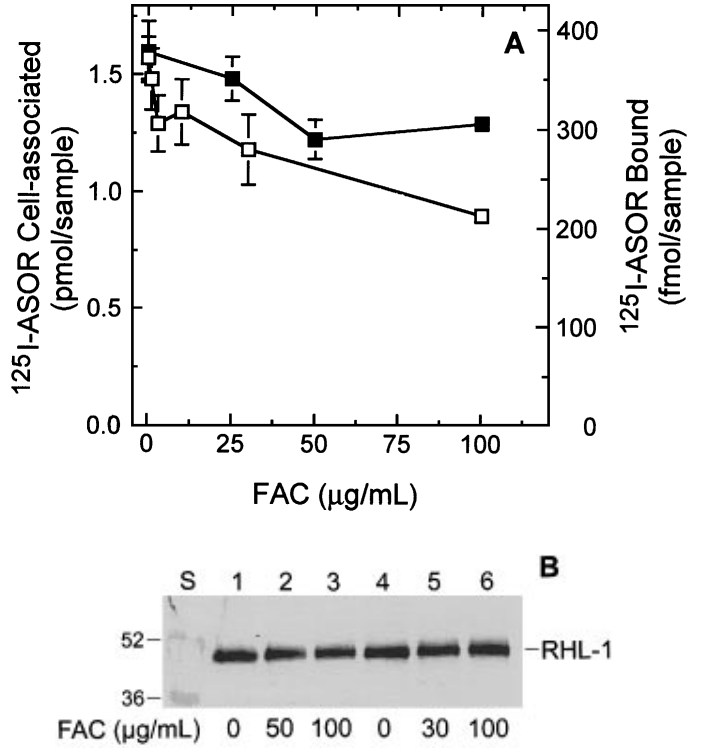

Figure 3 Effect of iron loading on immunodetectable RHL-1 content of hepatocytes

(A) Hepatocytes $\left(2 \times 10^{6} \mathrm{cell} / \mathrm{s} / \mathrm{ml}\right)$ were treated with $0-100 \mu \mathrm{g} / \mathrm{ml}$ FAC for $2 \mathrm{~h}$ at $37^{\circ} \mathrm{C}$, after which the cells were assayed for ${ }^{125}$-ASOR endocytosis at $37^{\circ} \mathrm{C}(\square)$ and total cellular ASGP receptor ligand-binding activity at $4^{\circ} \mathrm{C}(\boldsymbol{\square})$, as described in the Materials and methods section. Values represent means of duplicate samples; error bars reflect S.D. values of means. (B) Samples derived from experiments described for (A) which contained equivalent amounts of cells treated with the designated concentrations of FAC were subjected to SDS/PAGE and immunoblotted for the presence of RHL-1 using anti-RHL-1 serum as described in the Materials and methods section. Samples analysed on lanes 1-3 compared with lanes 4-6 used different hepatocyte preparations. Immunodetectable RHL-1 was quantified by laser scanning densitometry, and the peak areas [(absorbance units) $\cdot(\mathrm{mm})]$ were as follows: lane 1, 0.848; lane 2, 0.778; lane 3, 0.818; lane 4, 1.314; lane 5, 1.128; lane 6, 1.234. Molecular masses (kDa) are shown at the left. Abbreviation: S, molecular-mass standards.

and uptake of ${ }^{125}$ I-ASOR by hepatocytes was decreased by $60 \%$ following a $3 \mathrm{~h}$ incubation with FAC (Figure 1B). In other experiments, we examined the effects of iron loading on the ligand-binding activity of surface and intracellular ASGP receptors as well on the extent of ASOR internalization. We found that hepatocytes accumulated upward of 500 p.p.b. non-haem iron as a function of FAC treatment ( $\leqslant 100 \mu \mathrm{g} / \mathrm{ml}$; Figure $2 \mathrm{~A})$. Under these conditions, FAC treatment decreased hepatocyte accumulation of ${ }^{125}$ I-ASOR by up to $50 \%$ (Figure 2B), reflecting up to a $90 \%$ block in ${ }^{125}$ I-ASOR internalization. At the same time, the amount of ${ }^{125} \mathrm{I}$-ASOR bound on the surfaces of cells at $37^{\circ} \mathrm{C}$ (Figure $2 \mathrm{~B}, \triangle$ ) or at $4{ }^{\circ} \mathrm{C}$ (Figure $2 \mathrm{C}, \triangle$ ) remained nearly constant regardless of the amount of FAC treatment, indicating that iron loading did not adversely alter the ligand-binding activity of surface ASGP receptors. Moreover, we found that the total (surface and intracellular) ASGP receptor ligand-binding activity, when assayed at $4{ }^{\circ} \mathrm{C}$ on digitonin-permeabilized cells (Figure 2C), diminished by $\leqslant 26 \%$. Calculation of intracellular ASGP receptor ligand-binding activity from these data indicated that FAC treatment induced up to a $40 \%$ loss of intracellular receptor activity (Figure $2 \mathrm{C}, \mathbf{\square}$ ). Throughout the above experiments, cell samples maintained $\geqslant 75 \%$ viability as measured either by Trypan Blue exclusion or by release of lactate dehydrogenase, regardless of the treatment.

During recycling, a large fraction of ASGP receptors reversibly lose ligand-binding activity at an intracellular site [27], and receptor inactivation has been correlated with the reversible

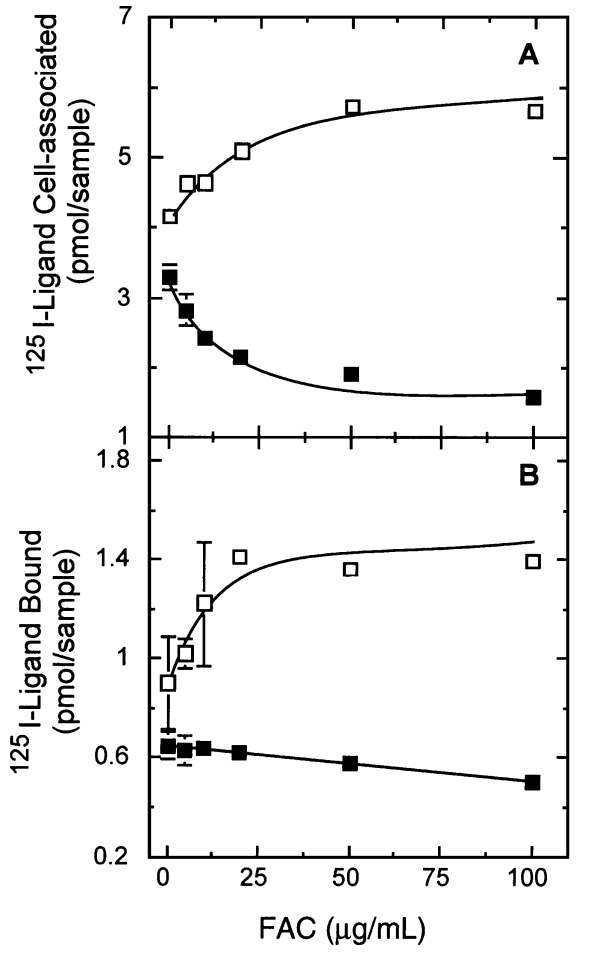

Figure 4 Effect of FAC treatment on hepatocyte binding and endocytosis of ASOR and Lf

(A) Hepatocytes $\left(2.4 \times 10^{6}\right.$ cells $\left./ \mathrm{ml}\right)$ were incubated with $0-100 \mu \mathrm{g} / \mathrm{ml}$ of FAC for $2 \mathrm{~h}$ at $37^{\circ} \mathrm{C}$, then supplemented with ${ }^{125} \mathrm{I}-\mathrm{Lf}(5 \mu \mathrm{g} / \mathrm{ml} ; \square)$ or ${ }^{125} \mathrm{I}-\mathrm{ASOR}(2 \mu \mathrm{g} / \mathrm{ml} ; \mathbf{\square})$ and incubated $1 \mathrm{~h}$ at $37^{\circ} \mathrm{C}$. Cells were rapidly chilled and assayed for total bound (surface and intracellular) radioactivity as described in the Materials and methods section. Symbols represent the means of duplicate samples; error bars reflect the S.D. values of the means. Best-fit isotherms were plotted according to the following equations: ${ }^{125} \mathrm{I}-\mathrm{Lf}, y=4.013 x^{0.8}(r=0.95)$; ${ }^{125}$ I-ASOR, $y=3.766 x^{-0.19}(r=0.99)$. (B) Hepatocytes $\left(2.4 \times 10^{6}\right.$ cells $\left./ \mathrm{ml}\right)$ were incubated with or without FAC as described for $(\mathbf{A})$. The cells were then assayed for binding of ${ }^{125}$-Lf $(\square)$ and ${ }^{125} \mathrm{I}$-ASOR $(\mathbf{\square})$ at $4{ }^{\circ} \mathrm{C}$ as described in the Materials and methods section. Symbols represent the means of duplicate samples; error bars reflect the S.D. values of the means. Bestfit isotherms were plotted according to the following equations: ${ }^{125} \mathrm{I}-\mathrm{Lf}, y=0.259 \log x+0.933$ $(r=0.83) ;{ }^{125}$-ASOR, $y=-0.001 x+0.648(r=0.99)$.

depalmitoylation of the receptor subunits [28,29]. Certain treatments (e.g. ATP depletion) block receptor re-activation (repalmitoylation) and induce cells to accumulate inactive ASGP receptors intracellularly with no loss of total cellular receptor protein [26,30]. To determine if iron loading was inducing receptor inactivation or receptor protein degradation, we treated cells with FAC and assayed for their content of RHL-1 (the major subunit of the ASGP receptor) as well as binding and endocytosis of ${ }^{125}$ I-ASOR (Figure 3). We found in two different experiments that treatment of cells with $100 \mu \mathrm{g} / \mathrm{ml} \mathrm{FAC} \mathrm{de-}$ creased immunodetectable RHL-1 on average $8.0 \pm 4.5 \%(n=$ 4) (Figure 3B). Under these conditions, ${ }^{125} \mathrm{I}$-ASOR bound and internalized by FAC-treated cells at $37^{\circ} \mathrm{C}$ was decreased $43 \%$ (Figure 3A), and ${ }^{125} \mathrm{I}$-ASOR binding at $4{ }^{\circ} \mathrm{C}$ to FAC-treated permeable cells was decreased by up to $23 \%$ (Figure $3 \mathrm{~A}$ ). We conclude from these data that loss of ASGP receptor protein could not account for the decrease in total cellular ASGP receptor ligand-binding activity in response to iron loading. Rather, iron loading of cells apparently induces a portion of the ASGP receptor population on these cells to be trapped in an inactive state. 


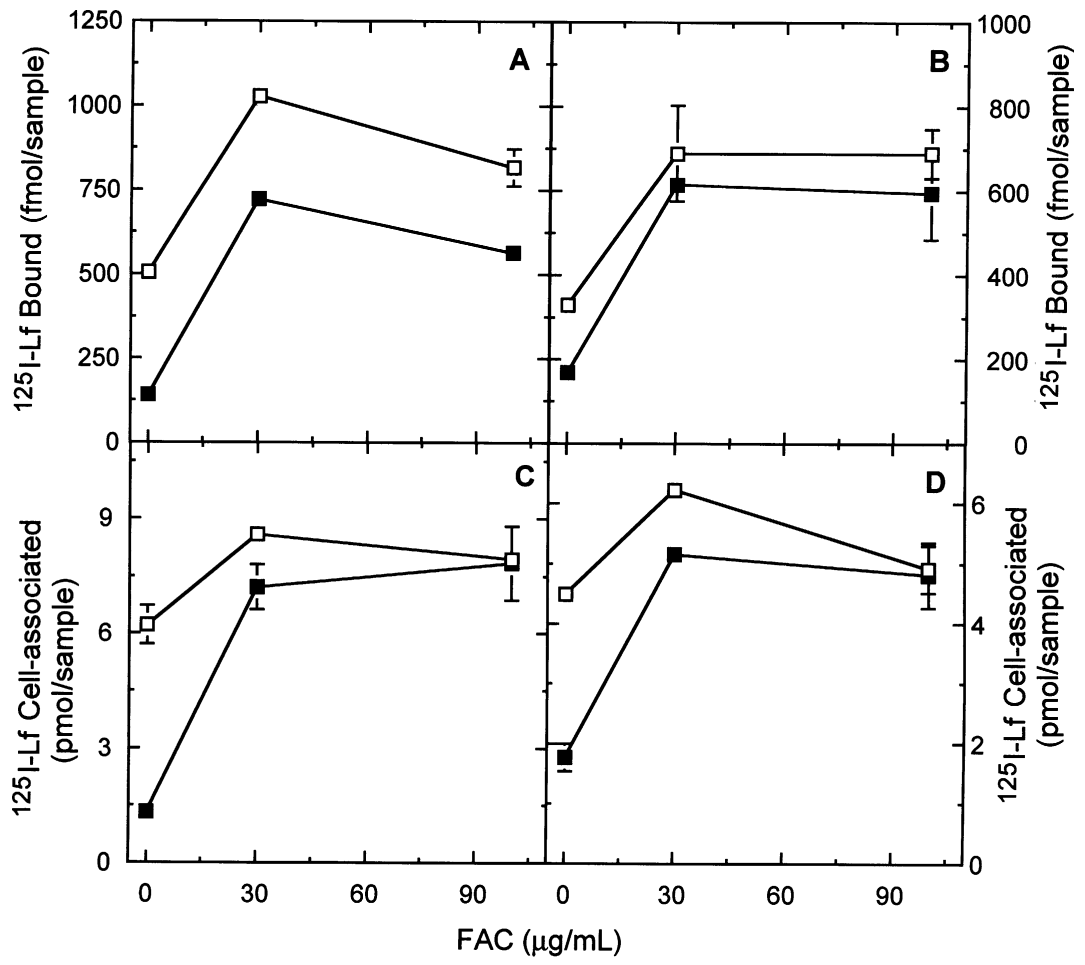

Figure 5 Effect of ASOR and anti-RHL-1 sera on ${ }^{125}$ I-Lf binding and uptake by FAC-treated hepatocytes

Hepatocytes $\left(2.4 \times 10^{6} \mathrm{cells} / \mathrm{ml}\right)$ were incubated with or without FAC $(0-100 \mu \mathrm{g} / \mathrm{ml})$ for $3 \mathrm{~h}$ at $37^{\circ} \mathrm{C}$. The cells were then assayed for ${ }^{125} \mathrm{I}-\mathrm{Lf}(2 \mu \mathrm{g} / \mathrm{ml})$ binding at $4{ }^{\circ} \mathrm{C}(\mathbf{A}, \mathbf{B})$ or endocytosis at $37^{\circ} \mathrm{C}(\mathbf{C}, \mathbf{D})$ in the absence $(\square)$ or presence $(\mathbf{\square})$ of a 50-fold molar excess of ASOR (A, C) or 1:100 dilution of anti-RHL-1 sera (B, D) for 60 min. The cells were then washed and assayed for cell-associated radioactivity as described in the Materials and methods section. Symbols represent the means of duplicate samples; error bars reflect the S.D. values of the means.

\section{Iron loading enhances Lf endocytosis by a non-ASGP receptor binding site}

We found recently that isolated rat hepatocytes bind and internalize the non-haem iron-binding glycoprotein Lf by the RHL-1 subunit of the ASGP receptor, but do so in a manner independent of the presence of terminal galactosyl or $N$-acetylgalactosaminyl groups on Lf $[15,16]$. Nonetheless, primary cultures of hepatocytes increase Lf binding and endocytic activity 2-6-fold following iron loading, an event that requires translation but not transcription and is concomitant with a decrease in ASOR endocytosis [17]. The transcription-independent manner by which iron loading enhances Lf receptor activity suggests that iron repletion releases an iron-regulatory protein-mediated block in translation of mRNA encoding these iron-dependent Lfbinding sites (for reviews see [31,32]). Because (i) RHL-1 mRNA lacks a consensus iron-responsive element [33] and (ii) iron loading induces a decrease in ASOR endocytosis, we propose that the Lf-binding site induced on iron-loaded hepatocytes is different from RHL-1. To confirm this hypothesis, we examined iron-loaded hepatocytes for changes in Lf and ASOR binding and endocytosis and determined whether selective blocking of RHL-1 activity would alter Lf uptake by these cells. When incubated with increasing amounts of FAC, hepatocytes bound and internalized up to $50 \%$ less ${ }^{125}$ I-ASOR compared with nontreated cells (Figure 4A). This was accompanied by less than a $20 \%$ loss in the number of active surface ASGP receptors as measured by the binding of ${ }^{125} \mathrm{I}-\mathrm{ASOR}$ to cells at $4{ }^{\circ} \mathrm{C}$ (Figure 4B). Under these conditions, however, ${ }^{125} \mathrm{I}-\mathrm{Lf}$ binding at $4{ }^{\circ} \mathrm{C}$ (Figure 4B) and endocytosis at $37^{\circ} \mathrm{C}$ (Figure 4A) increased, respectively, by up to 50 and $40 \%$ compared with non-iron- supplemented samples. We examined the ability of ASOR and anti-RHL-1 antibodies to block binding and endocytosis of ${ }^{125} \mathrm{I}$ Lf on control and FAC-treated hepatocytes. We reported previously that ASOR and anti-RHL-1 sera strongly compete with ${ }^{125} \mathrm{I}$-Lf for binding to RHL-1 on non-iron-supplemented cells [16], an observation confirmed by results shown in Figures 5(A) and 5(B). In contrast, as ${ }^{125} \mathrm{I}-\mathrm{Lf}$ binding (assayed at $4{ }^{\circ} \mathrm{C}$; Figures $5 \mathrm{~A}$ and $5 \mathrm{~B}$ ) and endocytosis (Figures $5 \mathrm{C}$ and $5 \mathrm{D}$ ) increased as a function of FAC treatment, neither excess molar ASOR (Figures 5A and 5C) nor anti-RHL-1 antibodies (Figures 5B and 5D) blocked the FAC-induced increase in binding or uptake. The absolute molar reduction of ${ }^{125} \mathrm{I}-\mathrm{Lf}$ binding exhibited by excess ASOR remained fairly constant as FAC was titrated (Figure $5 \mathrm{~A}$ ), even though ${ }^{125} \mathrm{I}-\mathrm{Lf}$ binding increased twofold. Accordingly, the level of ${ }^{125} \mathrm{I}-\mathrm{Lf}$ binding to hepatocytes in the presence of excess molar ASOR reflects the interaction of Lf with its ironinduced receptor alone. Taken together, these results indicate that hepatocytes express a non-RHL-1 Lf receptor following iron loading.

\section{Iron loading of hepatocytes blocks ASGP receptor internalization}

The foregoing results indicated that iron loading of hepatocytes blocked the endocytic activity ASGP receptors (Figure 2B). Moreover, iron-loaded cells accumulated a fraction of their intracellular ASGP receptors $(<40 \%)$ in an inactive form (Figure 2C) without substantially reducing the number of active ASGP receptors at the cell surface (Figures 2C and 4B). Because ASGP receptors recycle in the presence and absence of ligand, it is possible that iron loading interrupts ASGP receptor endocytic function by blocking internalization of receptor-ligand 


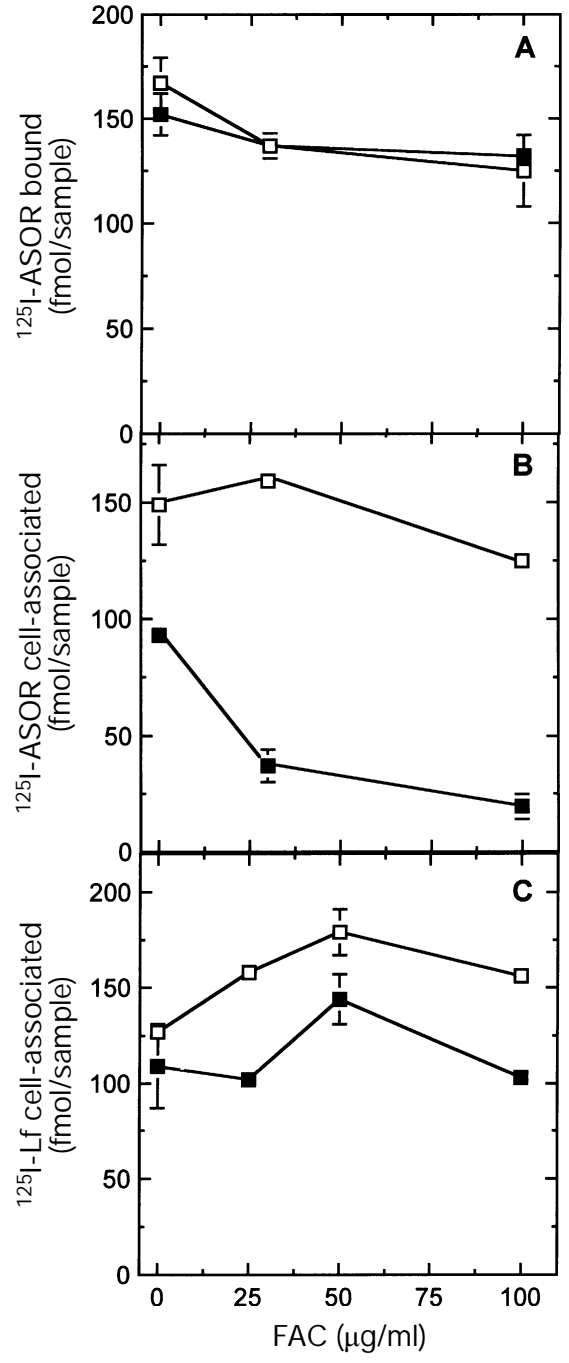

Figure 6 Effect of FAC treatment on surface ASGP receptor activity and internalization competence

(A) Hepatocytes $\left(2 \times 10^{6} \mathrm{cells} / \mathrm{ml}\right)$ were incubated with and without FAC in the presence ( $\square$ ) or absence ( $)$ of ASOR $(20 \mu \mathrm{g} / \mathrm{ml})$ for $1 \mathrm{~h}$ at $37^{\circ} \mathrm{C}$. Cells were chilled on ice, washed twice by centrifugation in Buffer $D$ to remove surface-bound ASOR, washed once with Buffer $A$, then assayed for ${ }^{125}$-ASOR binding at $4^{\circ} \mathrm{C}$ as described in the Materials and methods section. Symbols represent the means of triplicate samples; error bars reflect the S.D. values of the means. (B and C) Hepatocytes $\left(2.5 \times 10^{6} \mathrm{cell} / \mathrm{s} / \mathrm{ml}\right)$ were treated with or without the designated concentration of FAC for $2 \mathrm{~h}$ at $37^{\circ} \mathrm{C}$. The cells were chilled on ice and bound at $4{ }^{\circ} \mathrm{C}$ with either ${ }^{125} \mathrm{I}-\mathrm{ASOR}(\mathbf{B} ; 1 \mu \mathrm{g} / \mathrm{ml})$ or ${ }^{125} \mathrm{I}-\mathrm{Lf}(\mathbf{C} ; 2 \mu \mathrm{g} / \mathrm{ml})$ for $90 \mathrm{~min}$, after which the cells were washed free of unbound ${ }^{125}$-ligand. The cells were then placed into fresh BME/BSA containing the appropriate amount of FAC and incubated for $15 \mathrm{~min}$ at $37^{\circ} \mathrm{C}$ to allow uptake of prebound 125-ligand. The cells were chilled and assayed for total bound $(\square)$ and internal radioactivity as described in the Materials and methods section. Symbols represent the means of duplicate samples; error bars reflect the S.D. values of the means.

complexes at the cell surface or by disrupting recycling of ASGP receptors during ASOR endocytosis. To address the latter possibility, we assayed the number of active ASGP receptors on control and iron-supplemented cells treated in the presence or absence of unlabelled ASOR. Our rationale was that if iron loading disrupts recycling of ASGP receptors during endocytosis, then cells exposed to ASOR during FAC treatment might redistribute ASGP receptors from the cell surface to the cell interior compared with FAC-treated cells not actively internalizing ASOR. We found, however, that cells incubated with
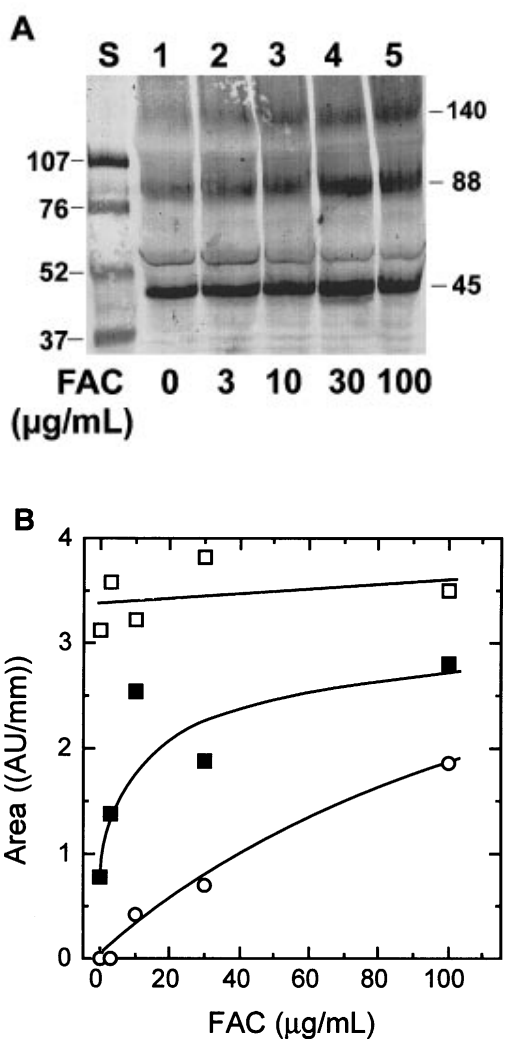

Figure 7 FAC treatment induces the formation of RHL-1 multimers

Hepatocytes $\left(2 \times 10^{6} \mathrm{cell} / \mathrm{s} / \mathrm{ml}\right)$ were treated with or without the designated concentration of FAC at $37^{\circ} \mathrm{C}$ for $2 \mathrm{~h}$, chilled on ice and pelleted by centrifugation. The cells were resuspended $\left(2 \times 10^{6}\right.$ cells/ml) into HBS containing $0.1 \%$ (w/v) digitonin, $9.2 \mathrm{mg} / \mathrm{ml}$ iodoacetamide and $0.5 \mathrm{mM}$ PMSF and treated for $20 \mathrm{~min}$ at $4{ }^{\circ} \mathrm{C}$. Digitonin at this concentration permeabilizes hepatocytes without solubilizing ASGP receptors [25]. Cell ghosts were pelleted by centrifugation and solubilized for $35 \mathrm{~min}$ at $4{ }^{\circ} \mathrm{C}$ in $0.15 \mathrm{M} \mathrm{NaCl} / 20 \mathrm{mM}$ Tris $(\mathrm{pH} 8.0) / 1 \%(\mathrm{v} / \mathrm{v})$ Triton $\mathrm{X}$ 100/0.5 mM PMSF at a density of $10^{7}$ ghosts per $\mathrm{ml}$. Detergent extracts were clarified by centrifugation $\left(15000 \mathrm{~g}, 10 \mathrm{~min}, 4^{\circ} \mathrm{C}\right)$. (A) Detergent extracts were fractionated by SDS/PAGE and probed for the presence of RHL-1 by immunoblot as described in the Materials and methods section. Lanes $1-5$, detergent extracts of cells that had been treated with $0,3,10$, 30 and $100 \mu \mathrm{g} / \mathrm{ml}$ of FAC respectively. Lane $\mathrm{S}$, molecular-mass standards ( $\mathrm{KDa}$ ); masses are shown on both sides of the blot. (B) The immunoblot from (A) was subjected to laser

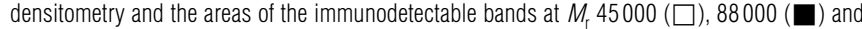
$140000(\bigcirc)$ were quantified. Best-fit isotherms were calculated according to the following equations: $45000, y=0.002 x+3.393(r=0.287) ; 88000, y=1.313 x^{0.16}(r=0.74)$; $140000, y=0.087 x^{0.652}(r=0.99)$. Abbreviation: AU, absorbance units.

ASOR for $2 \mathrm{~h}$ in the presence of $100 \mu \mathrm{g}$ of $\mathrm{FAC} / \mathrm{ml}$ expressed the same number of active ASGP receptors as did non-ASOR supplemented cells when assayed subsequently for ${ }^{125} \mathrm{I}-\mathrm{ASOR}$ binding at $4{ }^{\circ} \mathrm{C}$ (Figure 6A).

We then examined whether iron loading of the cells blocked internalization per se at the cell surface. Control and FACtreated hepatocytes were assayed for uptake of ${ }^{125} \mathrm{I}-\mathrm{Lf}$ and ${ }^{125} \mathrm{I}$ ASOR prebound to cells at $4{ }^{\circ} \mathrm{C}$ (Figure 6B). FAC-treated cells internalized $\geqslant 66 \%$ of prebound ${ }^{125} \mathrm{I}$-Lf, equivalent to $\geqslant 76 \%$ of the fraction internalized by untreated control cells. On the other hand, internalization of prebound ${ }^{125} \mathrm{I}-\mathrm{ASOR}$ by FACtreated cells was blocked by over $80 \%$. Taken together, these data indicate that iron loading selectively impaired the ability of ASGP receptors to internalize bound ASOR at the cell surface.

Because FAC-treated hepatocytes were fully capable of internalizing prebound $\mathrm{Lf}$, we reasoned that iron loading of cells induced a functional inhibition in ASGP receptors' endocytic 
activity without significantly altering the ligand-binding activity of cell-surface receptors or the internalization machinery of the clathrin-dependent endocytic pathway. Increased cellular iron content may lead to oxidation of ASGP receptor subunits in such a way that prevents receptor entry into clathrin-coated pits. One possibility is that $\mathrm{Fe}^{3+}$-dependent loading may induce disulphide bond formation between adjacent receptor subunits or between receptor subunits and other polypeptides, an association that blocks the receptor's ability to enter the cell. To test for this, we subjected detergent extracts of control and iron-loaded cells to SDS/PAGE under non-reducing conditions and looked for electrophoretic mobility changes of RHL-1 by immunoblot (Figure 7). Following treatment, chilled cells were treated with iodoacetamide to alkylate unreacted free sulphydryl groups before solubilization in non-reducing sample buffer. As expected, RHL-1 isolated from non-treated cells migrated predominantly as a monomer $(42 \mathrm{kDa})$ with a minor species $(\leqslant 25 \%$ of RHL1 present) at $88 \mathrm{kDa}$ (Figure 7A, lane 1; compare with Figure 3B, lanes 1 and 4). As FAC was titrated, we observed an increase in the amount of the $88 \mathrm{kDa}$ species as well as the evolution of a higher-molecular-mass species of $\approx 140 \mathrm{kDa}$. The amount of the $88 \mathrm{kDa}$ species roughly trebled as the FAC concentration increased from $0-100 \mu \mathrm{g} / \mathrm{ml}$ (Figure 7B), and the amount of the $140 \mathrm{kDa}$ species constituted more than $65 \%$ of the amount of the $88 \mathrm{kDa}$ species detected at $100 \mu \mathrm{g} / \mathrm{ml} \mathrm{FAC}$. The FAC concentrations that correlated with the increase in RHL-1 multimers $(\geqslant 10 \mu \mathrm{g} / \mathrm{ml})$ corresponded well with the FACinduced inhibition of ASOR endocytosis observed in previous experiments (Figures 2A, 3A, 4A and 6B). Unexpectedly, we detected no significant loss of RHL-1 monomer as the amounts of multimers increased. In other experiments, we found that all of the $140 \mathrm{kDa}$ species and $\approx 90 \%$ of the $88 \mathrm{kDa}$ species were lost when these RHL-1-containing species were reduced with $\beta$ mercaptoethanol during SDS/PAGE. We conclude, therefore, from the above experiments that iron loading of hepatocytes promotes the formation of disulphide-bonded RHL-1 multimers that correlates with a loss of endocytic function and intracellular accumulation of inactive ASGP receptors.

\section{DISCUSSION}

The purpose of this study was to analyse the iron-induced loss of ASGP receptor endocytic activity on isolated rat hepatocytes [17]. We found that iron loading by treatment of cells with the ferric salt FAC elicited multiple inhibitory effects on the ASGP receptor endocytic and ligand-binding activities. First, we found that FAC-treated hepatocytes, although not impaired in binding ASOR at the cell surface, were markedly impaired in their ability to internalize bound ASOR from the cell surface. Secondly, FAC-treated hepatocytes accumulated inactive ASGP receptors. Most, if not all, inactive receptors accumulated intracellularly, and cell-surface ASGP receptor ligand-binding activity remained essentially constant regardless of the iron status of the cells. Thirdly, loss of endocytic activity coincided with the formation of RHL-1-containing multimers of molecular masses estimated at 88 and $140 \mathrm{kDa}$ by SDS/PAGE. Formation of RHL-1 multimers was reversed by reducing agents, indicating that the 88 and $140 \mathrm{kDa}$ species contained disulphide-bonded RHL-1.

\section{Iron-dependent effects on asialoglycoprotein receptor dynamics}

Our findings presented here indicate that iron loading of hepatocytes significantly alters the movement of ASGP receptors between the cell surface and intracellular receptor pools. FAC treatment blocks the entry of ASGP receptor-ligand complexes into the cell at the cell surface (Figure 6B). Also, our data suggest that the delivery of intracellular receptors to the cell surface was also blocked, because the number of active ASGP receptors on cells did not change significantly as a result of iron loading (Figure 6A), even when cells were subjected to an endocytic load during iron treatment. If iron loading blocked only internalization, then recycling ASGP receptors returning to the cell surface after their intracellular sojourn would accumulate on the cell surface due to their inability to be re-internalized. Our findings do not exclude the possibility that movement of ASGP receptors between various intracellular compartments is unimpaired in iron-loaded cells.

\section{Iron induces expression of Lf receptor activity that is not RHL-1}

We have shown previously that adult hepatocytes in culture express an iron-induced Lf receptor activity that increases their ability to bind and internalize Lf. Our data presented here indicate that the induced Lf receptor activity is not RHL-1, based on several results. First, iron loading of hepatocytes greatly impairs receptor-mediated endocytosis of ASOR but enhances uptake of Lf (Figure 4). Secondly, the internalization block that iron loading imposes on ASOR uptake is not observed for $\mathrm{Lf}$ (compare Figures 6B and 6C). Thirdly, excess amounts of either anti-RHL-1 antibodies or ASOR block Lf uptake on control cells but had little or no inhibitory effect on Lf binding or uptake on iron-loaded cells (Figure 5). In other experiments, we have found that the iron-induced Lf-binding sites bind Lf independently of $\mathrm{Ca}^{2+}$ in a manner that is sensitive to $0.5 \mathrm{M} \mathrm{NaCl}$, unlike Lf's interaction with RHL-1 (D. D. McAbee, Y. Y. Ling and C. Stich, unpublished work) $[15,16]$. Notably, we showed previously that expression of the iron-inducible Lf-binding site does not require transcription and that expression is reversed upon removal of iron [17], reminiscent of the manner by which the levels of the ferritin $\mathrm{H}$ and $\mathrm{L}$ chains are regulated posttranscriptionally $[34,35]$. We conclude, therefore, that the ironinduced $\mathrm{Lf}$ receptor activity is not RHL-1 but another membrane component whose mRNA translation is positively regulated by the iron status of cells. At present, we are investigating the nature of this iron-inducible Lf-binding site.

\section{RHL-1 multimer formation, receptor inactivation, and inhibition of receptor internalization}

As shown in Figure 7, iron loading increases the formation of RHL-1-containing multimers that are detected when membrane proteins are alkylated and electrophoresed under non-reducing conditions. The sizes and sensitivity toward reducing agents of these higher-molecular-mass species ( 88 and $140 \mathrm{kDa}$ ) suggest they consist of disulphide-bonded dimers and trimers of RHL-1 (monomer size $42 \mathrm{kDa}$ ). At present, we cannot rule out the possibility that the $140 \mathrm{kDa}$ species may consist of an RHL-1 dimer crosslinked to a monomer of RHL-2/3 or some other polypeptide. It is also possible that the $140 \mathrm{kDa}$ species represents an RHL-1 monomer disulphide bonded to an unknown $\approx 90$ kDa polypeptide adduct.

The appearance of RHL-1 multimers occurred when hepatocyte non-haem iron content had increased by no more than 2-5fold at FAC concentrations between 3 and $30 \mu \mathrm{g} / \mathrm{ml}$ (Figure $2 \mathrm{~A})$, concentrations at which accumulation of inactive ASGP receptors (Figures $2 \mathrm{~B}$ and $2 \mathrm{C}$ ) and inhibition of receptor-ligand internalization (Figure 6B) occurred. This suggests that formation of RHL-1-multimers is (i) responsible for one or more of the inhibitory effects of iron loading on ASGP receptor activity or (ii) occurs as a result of the block in ASGP receptor dynamics due to as yet unknown mechanisms. 
RHL-1 contains ten Cys residues [36]: eight Cys sidechains in the extracellular domain of RHL-1 participate in stable cystine bridges [37], one Cys $\left(\mathrm{Cys}^{56}\right)$ is present within the subunit's transmembrane domain, and one Cys $\left(\mathrm{Cys}^{35}\right)$ is present on the cytoplasmic domain. It has been shown recently that all subunits of the rat and human ASGP receptors are palmitoylated $[29,38]$; acylation occurs on $\mathrm{Cys}^{35}$, present on each of the cytoplasmic tails of these receptor subunits [37]. Notably, methylaminedependent depalmitoylation results in the inactivation of rat and human ASGP receptors with a concomitant formation of disulphide-bonded homodimers of the deacylated receptor subunits [37]. Thus, it is proposed that reversible palmitoylation provides the mechanism by which these receptors undergo inactivation/ reactivation during recycling in hepatocytes [39]. These findings explain the iron-dependent accumulation of inactive ASGP receptors reported here. As ASGP receptors undergo routine depalmitoylation intracellularly, the elevated content of cellular iron may oxidatively promote cystine formation between $\mathrm{Cys}^{35}$ on adjacent RHL-1 subunits, a modification that precludes either re-acylation of $\mathrm{Cys}^{35}$ or delivery of $\mathrm{Cys}^{35}$-linked RHL-1 dimers to the re-acylation compartment. As a result, a significant fraction of ASGP receptors accumulate in an inactive form. Notably, the presence of ascorbate, which reductively promotes iron uptake in hepatocytes [40], enhances the iron-dependent block on ASGP receptor function (results not shown), suggesting that increased intracellular iron pools promote this inhibitory effect.

The mechanism by which iron loading blocks receptor internalization is unclear. It is unlikely that the iron effect on endocytosis is general, because the uptake of Lf by FAC-treated cells was largely unaffected whereas the block on ASGP receptor internalization was strong. One possibility is that the formation of RHL-1-containing multimers blocks the ability of ASGP receptors to incorporate into clathrin-coated pits. If the $140 \mathrm{kDa}$ species represents an RHL-1 homotrimer, then iron loading may promote the formation of a cystinyl bridge between the Cys ${ }^{56}$ sidechains of an RHL-1 monomer and a $\mathrm{Cys}^{35}$-Cys ${ }^{35}$-linked RHL-1 dimer. Because the native oligomeric structure of the ASGP receptor is a homo- or hetero-hexamer of receptor subunits $[41,42]$, it is possible that cystinyl-linked RHL-1 trimers could preclude internalization of most ASGP receptors even if not all receptor subunits were crosslinked. This could account for the observation that roughly half of the RHL-1 subunits detected on iron-loaded cells were disulphide-bonded multimers yet receptor internalization was blocked by up to $90 \%$ (Figure 6B). Such multimer formation may also restrict the return movement of ASGP receptors from the intracellular compartment back to the cell surface. At present, we are investigating the adducts cystinyl linked to RHL-1 in response to iron loading of hepatocytes.

Our observation that the amount of immunodetectable RHL1 monomer did not decrease during the iron-dependent appearance of RHL-1-containing multimers (Figure 7) was surprising, and we cannot explain it definitively at present. It is possible that immunodetection of RHL-1 on heavily loaded nitrocellulose protein replicas may lose some linearity of sensitivity such that relatively minor losses of RHL-1 monomer are less readily detected on blots than the appearance ex nihilo of RHL-1-containing multimers. A more interesting possibility is that iron loading induces an increase in the biosynthesis of ASGP receptors. We have not observed, however, notable irondependent changes in immunodetectable RHL-1 monomer by Western blots when SDS/PAGE was run under reducing conditions (results similar to that shown in Figure 3B). Nonetheless, experiments are in progress to determine if iron loading does alter ASGP receptor expression.

We thank Dr. Charles ('Go Blue') Kulpa and Dr. Jinesh Jain (Center for Environmental Science and Technology, University of Notre Dame, Notre Dame, IN, U.S.A.) for their assistance with the inductively coupled plasma MS. We also thank Dr. Roger Acey, Dr. Jeff Cohlberg and Dr. Paul Weigel for their helpful comments during the preparation of the manuscript. This work was supported by National Institutes of Health grant DK-43355.

\section{REFERENCES}

1 Kaplan, J., Jordan, I. and Sturrock, A. (1991) J. Biol. Chem. 266, 2997-3004

2 Beard, J. L., Dawson, H. and Pinero, D. J. (1996) Nutr. Rev. 54, 295-317

3 Desvergne, B., Baffet, G., Loyer, P., Rissel, M., Lescoat, G., Guguen-Guillouzo, C. and Brissot, P. (1989) Eur. J. Cell Biol. 49, 162-170

4 Fields, M. and Lewis, C. G. (1997) Metabolism 46, 377-381

5 Jensen, P. D., Heickendorff, L., Helweglarsen, H. M., Jensen, F. T., Christensen, T. and Ellegaard, J. (1996) Eur. J. Haematol. 57, 157-164

6 Livrea, M. A., Tesoriere, L., Pintaudi, A. M., Calabrese, A., Maggio, A., Freisleben, H. J., Darpa, D., Danna, R. and Bongiorno, A. (1996) Blood 88, 3608-3614

7 Moirand, R., Mortaji, A. M., Loreal, O., Paillard, F., Brissot, P. and Deugnier, Y. (1997) Lancet 349, 95-97

8 Pietrangelo, A., Rocchi, E., Schiaffonati, L., Ventura, E. and Cairo, G. (1990) Hepatology 11, 798-804

9 Stal, P., Johansson, I., Ingelmansundberg, M., Hagen, K. and Hultcrantz, R. (1996) J. Hepatol. 25, 538-546

10 LeClerc, L., Vasseur, C., Bursaux, E., Marden, M. and Poyart, C. (1988) Biochim. Biophys. Acta 946, 49-56

11 LeClerc, L., Marden, M. and Poyart, C. (1991) Biochim. Biophys. Acta 1062, 35-38

12 Beppu, M., Takahashi, T., Kashiwada, M., Masukawa, S. and Kikugawa, K. (1994) Arch. Biochem. Biophys. 312, 189-197

13 Adamson, G. M. and Harman, A. W. (1993) Biochem. Pharmacol. 45, 2289-2294

14 Liu, H., Lightfoot, R. and Stevens, J. L. (1996) J. Biol. Chem. 271, 4805-4812

15 Bennatt, D. J. and McAbee, D. D. (1997) Biochemistry 36, 8359-8366

16 Bennatt, D. J., Ling, Y. Y. and McAbee, D. D. (1997) Biochemistry 36, 8367-8376

17 McAbee, D. D. and Ling, Y. Y. (1997) J. Cell. Physiol. 171, 75-86

18 Rouault, T. A. and Klausner, R. D. (1996) J. Biol. Inorg. Chem. 1, 494-499

19 Seglen, P. O. (1973) Exp. Cell Res. 82, 391-398

20 McAbee, D. D. and Esbensen, K. (1991) J. Biol. Chem. 266, 23624-23631

21 Schachter, H., Jabbal, I., Hudgin, R. L., Pinteric, L., McGuire, E. J. and Roseman, S. (1970) J. Biol. Chem. 245, 1090-1100

22 Brown, E. M. and Parry, R. M. (1974) Biochemistry 13, 4560-4565

23 Hashizume, S., Kuroda, K. and Murakami, H. (1987) Methods Enzymol. 147, 302-314

24 Fraker, P. J. and Speck, J. C. (1978) Biochem. Biophys. Res. Commun. 80, 849-857

25 Weigel, P. H., Ray, D. A. and Oka, J. A. (1983) Anal. Biochem. 133, 437-449

26 McAbee, D. D., Lear, M. C. and Weigel, P. H. (1991) J. Cell. Biochem. 45, 59-68

27 McAbee, D. D. and Weigel, P. H. (1988) Biochemistry 27, 2061-2069

28 Zeng, F.-Y. and Weigel, P. H. (1995) J. Biol. Chem. 270, 21388-21395

29 Zeng, F.-Y., Oka, J. A. and Weigel, P. H. (1996) Biochem. Biophys. Res. Commun. 218, 325-330

30 McAbee, D. D. and Weigel, P. H. (1987) J. Biol. Chem. 262, 1942-1945

31 Theil, E. C. (1994) Biochem. J. 304, 1-11

32 Rouault, T. A. and Klausner, R. D. (1996) Trends Biochem. Sci. 21, 174-177

33 Leung, J. 0., Holland, E. C. and Drickamer, K. (1985) J. Biol. Chem. 260, 12523-12527

34 Aziz, N. and Munro, H. N. (1987) Proc. Natl. Acad. Sci. U.S.A. 84, 8478-8482

35 Toth, I., Rogers, J. T., McPhee, J. A., Elliott, S. M., Abramson, S. L. and Bridges, K. R. (1995) J. Biol. Chem. 270, 2846-2852

36 Drickamer, K., Mamon, J. F., Bins, G. and Leung, J. O. (1984) J. Biol. Chem. 259, 770-778

37 Zeng, F.-U. and Weigel, P. H. (1996) J. Biol. Chem. 271, 32454-32460

38 Zeng, F.-Y., Kaphalia, B. S., Ansari, G. A. S. and Weigel, P. H. (1995) J. Biol. Chem. 270, 21383-21387

39 Weigel, P. H., Medh, J. D. and Oka, J. A. (1994) Mol. Biol. Cell 5, 227-235

40 Trinder, D., Batey, R. G., Morgan, E. H. and Baker, E. (1990) Am. J. Physiol. 259, G611-G617

41 Sawyer, J. T., Sanford, J. P. and Doyle, D. (1988) J. Biol. Chem. 263, 10534-10538

42 Herzig, M. C. S. and Weigel, P. H. (1990) Biochemistry 29, 6437-6447 